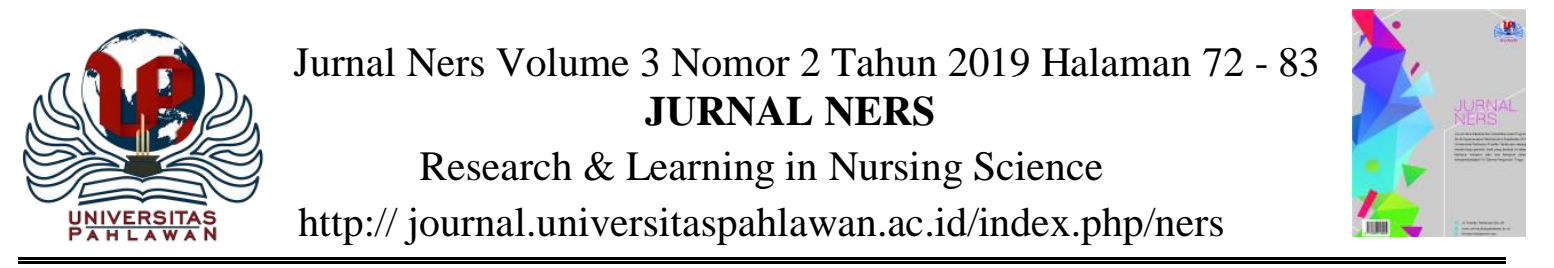

\title{
PENGARUH PEMBERIAN JUS BAYAM MERAH, JERUK SUNKIS, MADU TERHADAP KADAR HEMOGLOBIN PADA IBU HAMIL YANG MENGALAMIANEMIA DI UPT PUSKESMAS KAMPAR TAHUN 2019
}

\author{
Yenny Safitri \\ Universitas Pahlawan Tuanku Tambusai \\ yennysafitri37@yahoo.co.id
}

\begin{abstract}
ABSTRAK
Anemia yaitu kadar hemoglobin $<11$ gr\%. Anemia defisiensi zat besi adalah kondisi kekurangan nutrisi zat besi yang mengakibatkan penurunan jumlah sel darah merah.Anemia defisiensi zat besi pada ibu hamil ini dapat menimbulkan dampak besar bagi kehamilan seperti perdarahan, kematian ibu, prematuritas, kematian perinatal dan BBLR.Untuk mengatasi anemia pada kehamilan ini salah satunya dengan menggunakan terapi kombinasi jus bayam merah-jeruk sunkis-madu. Tujuan penelitian untuk mengetahui pengaruh pemberian jus bayam merah-jeruk sunkis-madu terhadap kadar hemoglobin pada ibu hamil yang mengalami anemia. Metode penelitian ini menggunakan jenis penelitian kuantitatif.Desain penelitian menggunakan quasi experiment, rancangan yang digunakan one group pre-test-posttest.Sampel dalam penelitian ini menggunakan teknik purposive sampling.Populasi dalam penelitian ini adalah ibu hamil yang berkunjung ke Puskesmas yang mengalami anemia dari bulan januari-juli 2018 sebanyak 228 orang. Jumlah sampel dalam penelitian ini sebanyak 15 orang dengan usia kehamilan Trimester 3. Instrumen dalam penelitian ini menggunakan alat pengukur kadar hemoglobin digital. Data di analisis melalui dua tahapan yaitu analisa univariat dan bivariat dengan menggunakan uji $T$ dependent (paired sample test). Hasil penelitian terapi kombinasi jus bayam merah-jeruk sunkis-madu berpengaruh dalam meningkatkan kadar hemoglobin pada ibu hamil yang mengalami anemia (p : $0.000<0,05)$ di UPT Puskesmas Kampar Tahun 2019. Penelitian ini sebagai alternatif bagi ibu hamil agar dapat mengkonsumsi jus bayam merah-jeruk sunkis-madu untuk mengurangi prevalensi angka kejadian anemia pada ibu hamil selain mengkonsumsi tablet Fe.
\end{abstract}

Kata Kunci : Anemia, kadar hemoglobin, ibu hamil, jus bayam merah-jeruk sunkis-madu

Daftar Pustaka : 35 (2007-2017)

$\triangle$ Corresponding author :

Address : Jl. Tuanku Tambusai No. 23 Bangkinang

Email : yennysafitri37@yahoo.co.id

Phone : 085265460467 


\section{BAB I}

\section{PENDAHULUAN}

\section{A. Latar Belakang}

Anemia merupakan suatu keadaan menurunnya kadar hemoglobin, hematokrit, dan jumlah eritrosit dibawah nilai normal. Anemia juga sering disebut KD (kurang darah) yaitu keadaan dimana kadar hemoglobin dalam darah kurang dari normal $(<12 \mathrm{gr} \%)$. Penyebab biasanya kurangnya zat gizi untuk pembentukan darah, misalnya zat besi, asam folat, dan vitamin B12. Tetapi yang biasa terjadi adalah anemia defisiensi zat besi (Rukiyah dkk,2010).

Anemia defisiensi zata besi adalah kondisi kekurangan nutrisi zat besi yang mengakibatkan penurunan jumlah sel darah merah.Etiologi anemia defisiensi besi pada kehamilan, yaitu : 1) Hipervolemia, menyebabkan terjadinya pengenceran darah, 2) Perubahan darah tidak sebanding dengan pertambahan plasma, 3) Kurangnya zat besi dalam makanan, dan 4) Zat besi meningkat (Manuaba, 2010).

Anemia defisiensi zat besi pada ibu hamil sebagai salah satu kelompok rawan dapat menimbulkan dampak yang besar bagi kehamilan. Bagi ibu hamil itu sendiri,kekurangan zat besi berasosiasi kurang menguntungkan untuk ibu dan bayi termasuk meningkatkan resiko perdarahan,sepsis,kematian ibu,prematuritas,kematian perinatal,dan berat badan lahir rendah. Serta kejadiananemia pada ibu hamil akan meningkatkan resiko terjadinya kematian ibu dibandingkandengan ibu yang tidak anemia(Depkes RI, 2009).
Untuk mengatasi anemia defisiensi zat besi pada ibu hamil bisa dilakukan secara medis dan non medis (komplementer).Terapi komplementer merupakan terapi alternatif yang digunakan bersama atau sebagai tambahan terhadap pengobatan konvensional (vitahealth, 2008).Terapi herbal biasanya sangat diminati oleh masyarakat selain merasa aman karena terbuat dari bahan yang berasal dari alam. Pembuatan dan bahannya juga mudahdidapat untuk di konsumsi sehari-hari.Terapi kombinasi yang berasal dari herbal ini dua diantaranya adalah bayam merah dan jeruk sunkis dikombinasikan dengan madu.

Bayam salah satu sayuran yang banyak mengandung zat besi, dimana zat besi merupakan salah satu nutrien yang sangat penting dikonsumsi selama hamil (Bobak, 2008). Ada dua jenis bayam, yaitu bayam merah dan bayam hijau.Bayam merah dan bayam hijau sebenarnya sama-sama memiliki manfaat yang baik. Di dalam 100 gr bayam hijau mengandung energi sebesar $16 \mathrm{Kkal}$, 0,9 protein, 0,4 gr lemak, 2,9 gr karbohidrat, $166 \mathrm{mg}$ kalsium, 0,7 gr serat, 3,5 $\mathrm{mg}$ zat besi dan $41 \mathrm{mg}$ vitamin C. Sedangkan untuk 100 gr bayam merah mengandung energi sebesar $50 \mathrm{Kkal}, 3$ gr protein, 0,8 gr lemak, 10 gr karbohidrat, $520 \mathrm{mg}$ kalsium, 2,2 gr serat, $7 \mathrm{mg}$ zat besi dan $62 \mathrm{mg}$ vitamin C. Untuk itu pencegahan agar tidak terjadinya anemia sebaiknya mengkonsumsi bayam terutama bayam merah yang memiliki kandungan zat besi dan vitamin $\mathrm{C}$ yang lebih tinggi dibandingkan dengan bayam hijau.Adapun kebutuhan zat besi untuk ibu hamil $>20 \mathrm{mg}$. 
Disamping itu, zat besi merupakan zat yang diserap oleh tubuh maka dibutuhkan vitamin $\mathrm{C}$ agar zat besi dapat diserap secara maksimal. Hal ini sesuai dengan hasil penelitian Zulaekah (2007) yang menyatakan bahwa pemberian suplemen zat besi dan vitamin $\mathrm{C}$ lebih efektif meningkatkan kadar hemoglobin dan jumlah sel darah merah dibandingkan dengan zat besi saja atau vitamin $C$ saja.

Salah satu buah yang memiliki vitamin $\mathrm{C}$ dan senyawa bermanfaat untuk kesehatan adalah jeruk. Selain banyak mengandung vitamin $\mathrm{C}$, jeruk juga merupakan buah yang enak untuk dikonsumsi. Selain vitamin $\mathrm{C}$, buah jeruk juga banyak mengandung vitamin $\mathrm{B} 1$, provitamin A, asam folat, pektin, tanin, fosfor, kalsium, karbohidrat, besi, asam sitrat, flavonaid, glukosida, alkaloid, dan ester(Rozaline, 2008).

Ada berbagai jenis jeruk, yaitu jeruk sunkis, jeruk manis dan jeruk nipis. Namun memiliki kandungan vitamin $\mathrm{C}$ yang berbeda. Pada jeruk manis memiliki kandungan vitamin C 53,2 mg dan jeruk nipis kandungan vitamin $\mathrm{C}$ nya sebanyak $53 \mathrm{mg}$ sedangkan jeruk sunkis mengandung $70 \mathrm{mg}$ vitamin C. Jadi jeruk sunkis lebih tinggi kandungan vitamin $\mathrm{C}$ nya dibandingkan dengan jeruk manis dan jeruk nipis.Adapun kebutuhan vitamin $C$ untuk ibu hamil rata-rata sekitar $86 \mathrm{mg}$ per hari.

Madu merupakan obat dari segala jenis penyakit. Madu dapat digunakan sebagai perisa (pemanis) pada minuman. Madu kaya akan kandungan gizi mulai dari asam amino, zat gula glukosa dan fruktosa, vitamin, riboflavin, thiamin, asam pantotenat, niasin, asam askorbat, piridoksin, dan kandungan mineral seperti kalsium, kalium, magnesium, natrium, phosphor, zat besi, sulfut, dan mangan. Selain itu, madu juga dilengkapi dengan keunggulan lain yaitu kandungan antibiotik yang terdapat dalam tiap tetesnya. Itulah kenapa madu menjadi salah satu sumber energi yang sangat dianjurkan bagi ibu hamil (Dokter sehat, 2017).

Berdasarkan penelitian Titik Wijayanti (2006) menyatakan bahwa pemberian jus bayam pada tikus putih sangat efektif dalam meningkatkan kadar hemoglobin darah sebanyak 5\%.Berdasarkan hasil penelitian Nuraysih(2015) menunjukan bahwa kombinasi jus Bayam-Jeruk sunkis-Madu efektif untuk meningkatkan kadar hemoglobin pada ibu hamil dengan anemia di wilayah kerja UPTD Puskesmas Kecamatan Pontianak Selatan.

Menurut World Health Organization (WHO) pada tahun 2013memperkirakan bahwa ada 500.000 kematian ibu melahirkan di seluruh dunia setiap tahunnya, 99\% diantaranya terjadi di Negara berkembang. Dari angka tersebut diperkirakan bahwa hampir 1 orang ibu setiap menit meninggal akibat kehamilan dan persalinan.Angka kematian maternal di Negara berkembang diperkirakan mencapai 100-1000/100.000 kelahiran hidup.Sedang di Negara maju berkisar antara 7-15/100.000 kelahiran hidup. Ini berarti bahwa di Negara berkembang risiko kematian maternal 1 diantara 29 persalinan sedangkan di Negara maju 1 diantara 29.000 persalinan.

Menurut laporan pembangunan pada tahun 2013 tercatat angka kematian ibu di beberapa Negara 
Assosiation South East Asia Nations (ASEAN) seperti di Vietnam 18 per 100.000 kelahiran hidup, di Malaysia 5,5/100.000 kelahiran hidup, Filiphina 26 per 100.000 kelahiran hidup dan Singapura 3/100.000 kelahiran hidup. Sedangkan angka kematian diIndonesia mencapai 248/100.000 kelahiran hidup.

Data dari Kementerian Kesehatan menunjukkan angka kematian ibu saat melahirkan mengalami penurunan sejak tahun 2015 hingga tahun 2017. Angka kematian ibu saat melahirkan pada tahun 2015 sekitar 4.999 kasus, tahun 2016 sekitar 4.912 kasus, sementara di tahun 2017 terjadi 1.712 kasus kematian ibu saat proses persalinan.

Di Indonesia angka anemia kehamilan menunjukkan nilai yang cukup tinggi. Hoo Swie Tjiong menemukan angka anemia kehamilan pada trimester I sebanyak $3,8 \%$, trimester II yaitu $13,6 \%$ dan trimester III yaitu $24,8 \%$ dan tiap tahunnya wanita Indonesia meninggal karena kehamilan dan persalinan. (Manuaba I.G.B,2010).

Berdasarkan data Dinas Kesehatan Provinsi Riau tahun 2015 ditemukan anemia gizi besi pada ibu hamil sebesar 4\%, tahun 2016 sebesar 4,56\%dan tahun 2017 sebesar 5,1\%. Kabupaten Indragiri Hilir adalah salah satu Kabupaten yang berada di Provinsi Riau, pada tahun 2014jumlah kematian ibu di Kabupaten Indragiri Hilir adalah sebesar 23 orang, 50\% diantaranya disebabkan karena terjadinya perdarahan, yang diakibatkan karena terjadinya anemia pada ibu di masa kehamilan.

Berdasarkan data Dinas Kesehatan Kabupaten Kampar bahwa tahun 2015 ibu hamil yang mengkonsumsi tablet fe sebanyak 90,5\%, tahun 2016 ibu hamil mengkonsumsi tablet fe $80,4 \%$ dan tahun 2018sebanyak 90,3\%. Terjadi angka konsumsi tablet fe yang berfluktuatif.

Berdasarkan data UPT Puskesmas Kampar terjadi peningkatan kasus Anemia pada ibu hamil di Desa Batu Belah dari tahun ke tahun. Pada tahun 2014 kasus anemia pada ibu hamil berjumlah 142 orang. Pada tahun 2015 terjadi penurunan kasus ibu hamil dengan anemia yaitu berjumlah 142 orang dan pada tahun 2017 terjadi kenaikan angka kasus anemia pada ibu hamil yaitu berjumlah 158 orang. Dari keseluruhan total kehamilan yang ada, Ini berarti terjadi peningkatan kasus Anemia pada Ibu Hamil di tahun 2017. Data anemia perdesa untuk desa Batu Belah, pada tahun 2017 kasus anemia pada ibu hamil berjumlah 45 orang. Data anemia ibu hamil Januari - Juni 2019, Kelurahan Kampar berjumlah 80 orang, Berdasarkan survey awal yang dilakukan pada 10 orang ibu hamil, didapatkan data bahwa mereka semuanya mengetahui apa itu anemia, dan $40 \%$ yang mengetahu apa itu anemia defisiensi zat besi, $50 \%$ mengetahui penyebab anemia dan $60 \%$ mengetahui dampak dari anemia, 30\% mengetahui manfaat jus bayam hijau jeruk sunkis - madu dalam pengobatan anemia pada ibu hamil dan $10 \%$ yang mengetahu cara menggolah jus tersebut.

Berdasarkan wawancara dengan petugas kesehatan, mereka menyatakan bahwa penyuluhan tentang gizi ibu hamil selalu dilakukan setiap bulan, $100 \%$ ibu hamil yang melakukan pemeriksaan ke tenaga kesehatan namun ada ibu yang tidak mengkonsumsi tablet fe yang diberikan oleh petugas kesehatan. 
Berdasarkan latar belakang di atas maka penulis tertarik meneliti "Pengaruh pemberian jus bayam hijau jeruk sunkis - madu terhadap kadar hemoglobin pada ibu hamil dengan anemia di Puskesmas Kampar wilayah kerja UPT Puskesmas Kampar, Kabupaten Kampar tahun 2019”.

\section{B. Rumusan Masalah}

Dari paparan latar belakang di atas, maka penulis simpulkan masalah penelitian ini yaitu "Apakahada pengaruh pemberian jus bayam merah-jeruk sunkismaduterhadap kadar hemoglobin pada ibu hamil yang mengalami anemia di Puskesmas Kampar wilayah kerja UPT Puskesmas Kampar, Kabupaten Kampar tahun 2019

C. Tujuan Penelitian

1. Tujuan Umum

Secara umum penelitian ini bertujuan untuk mengetahui Pengaruh pemberian jus bayam hijau - jeruk sunkis - madu terhadap kadar hemoglobin pada ibu hamil dengan anemia di Kelurahan Kampar wilayah kerja UPT Puskesmas Kampar, Kabupaten Kampar tahun 2019”.

\section{Tujuan Khusus}

a. Mengetahui kadar hemoglobin ibu hamil sebelum diberikan jus bayam hijau - jeruk sunkis madu.

b. Mengetahui kadar hemoglobin ibu hamil setelah diberikan jus bayam hijau hijau - jeruk sunkis - madu.

c. Menganalisis efektifitas mengkonsumsi jus bayam hijau jeruk sunkis - madu terhadap pengaruh kadar hemoglobin ibu

BAB III hamil dengan anemia.

\section{METODOLOGI PENELITIAN}

\section{A. Desain Penelitian}

Pada penelitian ini menggunakan jenis penelitian kuantitatif. Desain penelitian yang digunakan yaitu quasi experiment, dan rancangan yang digunakan one group pre-testposttest yaitu dengan mengobservasi sebanyak 2 kali sebelum dan sesudah diberikan perlakuan, pemberian jus bayam merah-jeruk sunkis-madu 1 kali sehari selama 5 hari. Kelompok diobservasi sebelum dilakukan intervensi, kemudian diobservasi kembali setelah intervensi dilain waktu yang telah ditentukan (Setiadi, 2007).

\section{B. Lokasi dan Waktu Penelitian}

\section{Lokasi}

Penelitian dilakukan di wilayah UPT.Puskesmas Kampar tahun 2019.

\section{Waktu Penelitian}

Penelitian ini dilakukan pada tanggal 01-05 Agustus 2019.

\section{Populasi dan Sampel}

\section{Populasi}

Populasi dalam penelitian adalah subjek yang memenuhi kriteria yang telah ditetapkan (Nursalam, 2008). Populasi dalam penelitian ini adalah ibu hamil yang berkunjung ke UPT. Puskesmas Kamparyang mengalami anemia dari bulan januari - juli 2019 sebanyak 228 orang.

\section{Sampel}

Dalam penelitian ini peneliti menetapkan 15 orang sampelyaitu ibu-ibu yang mengalami Anemia Ringan $\mathrm{Hb}$ 9-10 gr\% dan Anemia Sedang $\mathrm{Hb} 7-8 \mathrm{gr} \%$.

Pengambilan sampel pada penelitian ini menggunakantekhnik purposive sampling yaitu suatu tekhnik penetapan sampel dengan cara memilih sampel diantara populasi 
sesuai dengan kriteria penelitian (Nursalam, 2008). Dalam pembuatan laporan ini, peneliti menentukan beberapa kriteria inklusi dan kriteria eksklusi yaitu:

\section{a. Kriteria Inklusi}

Kriteria inklusi adalah kriteria atau ciri-ciri yang harus dipenuhi setiap masing-masing anggota populasi yang akan dijadikan sampel(Notoatmodjo, 2010).

Yang termasuk kriteria inklusi yaitu :

1) Bertempattinggal di

Wilayah Kerja UPT.

Puskesmas kampar

2) Responden yang mengalami Anemia RinganHb 9-10 gr\% dan Anemia Sedang $\mathrm{Hb}$ 7-8 gr\%.

3) Tidak mengkonsumsi obatobatan (obatkimia) dan tidak konsumsi obat-obat tradisional selama dilakukan penelitian.

4) Responden harus mengikuti aturan dari peneliti.

5) Bersedia untuk dijadikan responden penelitian.

6) Responden yang diteliti usia kehamilan Trimester III.

\section{b. Kriteria Ekslusi}

Kriteria ekslusi adalah kriteria atau ciri-ciri anggota populasi yang tidak bisa dijadikan sebagai sampel penelitian (Notoatmodjo, 2010).

Yang termasuk dalam kriteria ekslusi yaitu :

1) Tidak bersedia menjadi responden.

2) Ibu hamil anemia dengan penyakit komplikasi.

3) Jika responden tiba-tiba pindah tempat tinggal atau pulang kampung, responden diganti dengan responden yang baru.

\section{Alat Pengumpulan Data}

Alat untuk melakukan pengumpulan data tentang kadar hemoglobin pada penelitian ini dengan menggunakan lembar observasi yang berisikan biodata responden dan alat pengukur hemoglobin digital. Metode yang digunakan untukmengetahui kadar hemoglobin sebelum dan sesudah tindakan dilakukan dengan cara mengukur nilai kadar hemoglobin ibu.

\section{E. Prosedur Pengumpulan Data}

Untuk memperoleh jenis data, peneliti memperoleh dengan metode sebagai berikut :

1. Sumber data Primer

Data primer adalah data yang diperoleh atau dikumpulkan oleh peneliti sendiri secara langsung terhadap sasaran. Adapunyang menjadi sumber data primer dalam penelitian ini adalah ibuibu hamil dengan anemia yang berkunjung ke wilayah kerja UPT. Puskesmas Kampar pada bulan Januari 2018.

2. Sumber data sekunder

Datasekunder adalah data yang diperoleh peneliti dari sumber yang sudah ada. Dapat juga dikatakan data yang sudah tersusun dalam bentuk dokumendokumen. Adapun yang menjadi sumber data sekunder dalam penelitian ini adalah dokumentasi dan catatan rekam medik Puskesmas.

\section{F. Analisis Data}

\section{Analisa Data}


Analisa data merupakan sebuah cara untuk mengolah data menjadi informasi agar karakteristik data tersebut mudah dipahami dan bermanfaat untuk solusi permasalahan, terutama hal yang berkaitan dengan penelitian.

a. Analisis Univariat

Menurut Hastono (2007), tujuan dari analisis univariat adalah untuk menjelaskan/mendeskripsikan karakteristik masing-masing variabel yang diteliti. Dalam penelitian ini analisa univariat akan

menjelaskan/mendeskripsikan tentang karakteristik responden (data umum) yaitu umur, riwayat kehamilan dan pekerjaan untuk memperoleh gambaran dari variabel yang diteliti yaitu variabel kadar hemoglobin.

b. Analisis Bivariat

Analisa bivariat dilakukan untuk mengetahui perbedaan antara kedua variabel. Pada penelitian ini, uji bivariat dilakukan untuk mengetahui perbedaan kadar hemoglobin pada saat pretest dan posttest(Hastono, 2007). Uji hipotesis yang digunakan adalah uji beda dua mean atau $T$ dependent (Paired Sample Test) untuk menganalisa selisih antara dua mean pada subjek sebelum dan setelah diberikan terapi jus bayam merah-jeruk sunkis-madu dengan nilai $p$ value $<0,05$.

\section{Pengolahan Data}

Pengolahan data adalah manipulasi data ke dalam bentuk yang lebih berarti berupa informasi. Pengolahan data dilakukan setelah data terkumpul, dianalisis, kemudian data diolah. Menurut Hidayat (2014), langkahlangkah pengolahan data sebagai berikut:

\section{a. Editing}

Peneliti mengecek kembali lembar observasi apakah lembar tersebut diisi sesuai dengan yang diobservasi seperti kadar hemoglobin sebelum dan setelah diberi perlakuan serta kelengkapan data karakteristik responden.

b. Coding

Mengubah data berbentuk huruf menjadi data berbentuk angka. Pada penelitian ini variabel kelompok penelitian dilakukan koding 1 = pretest dan 2 = postest. Hal ini berguna untuk mempermudah peneliti pada saat analisis data dan pemindahan data.

c. Entry data

Melakukan pemindahan data dari lembar observasi kedalam program komputer.

\section{d. Cleaning data}

Mengecek kembali apakah ada kesalahan data, sehingga data siap untuk dianalisa.

\section{BAB IV}

\section{HASIL PENELITIAN}

Penelitian ini dilakukan di wilayah kerja UPT Puskesmas Kampar Kabupaten kampar selama 5 hari berturut-turut. Sampel ditemui pada pagi hari antara jam 09.00-10.00 WIB. Mulai sejak tanggal 01-05 Juli 2019 dengan jumlah sampel sebanyak 15 orang ibu hamil yang sesuai dengan criteria inklusi dan diberikan jus bayam merah - jeruk sunkis - madu untuk melihat pengaruh jus bayam merah jeruk sunkis - madu terhadap 
peningkatan kadar hemoglobin pada ibu hamil yang mengalami anemia.

\section{B. Analisa Bivariat}

Analisa pengaruh pemberian jus bayam merah-jeruk sunkis-madu terhadap kadar hemoglobin pada ibu hamil yang mengalami anemia di UPT Puskesmas kampar Tahun 2019.

Tabel 4.3Data statistikkadar hemoglobin sebelum dan sesudah pemberian jus bayam merah - jeruk sunkis - madu di wilayahkerja UPT Puskesmas Kampar Tahun 2019 ( $\mathrm{N}=15$ )

\begin{tabular}{llll} 
Variabel Mean SD & Selisih & CI 95\% & P-Value \\
\hline Mean Lower Upper & & & \\
\hline
\end{tabular}

Sebelum mengkonsumsi 9.547

.6978

Jus bayam merah-jeruk

Sunkis-madu (pretest)

$1.34-1.4832-1.1968 .000$

\section{Sesudah mengkonsumsi $\quad 10.887 \quad .6278$}

Jus bayam merah-jeruk

Sunkis-madu (posttest)

\begin{tabular}{|c|c|c|}
\hline Berdasarkan & tabel & $\begin{array}{l}\text { peningatan } \\
\text { ibu hamil yang mengalami anemia di }\end{array}$ \\
\hline menunjukkan & jumlah & UPT Puskesmas Kampar Tahu \\
\hline responden 15 . & Sedangkan mean & 2019 \\
\hline
\end{tabular}

kadar hemoglobin sebelum mengkonsumsi jus bayam merahjeruk sunkis-madu adalah 9,547. Pada pengukuran sesudah pemberian jus bayam merah-jeruk sunkis-madu didapatkan nilai mean kadar hemoglobin sebesar 10,887. Nilai selisih mean antara pengukuran sebelum dan sesudah mengkonsumsi jus bayam merah-jeruk sunkis-madu yaitu -1,34, CI 95\% lower -1,4832 dan upper $-1,1968$.

Dengan menggunakan uji $\mathrm{T}$ sampel didapatkan hasil bahwa besarnya nilai $p$-value 0.000 dengan $\alpha 0,05$. Karena nilai $p$-value $<0,05$, dengan demikian dapat disimpulkan bahwa Ha diterima yang artinya ada pengaruh konsumsi jus bayam merah - jeruk sunkis-madu terhadap

\section{BAB V}

\section{PEMBAHASAN}

\section{A. PembahasanPenelitian}

Pengaruh pemberian jus bayam merah - jeruk sunkis-madu terhadap kadar

\section{hemoglobin pada ibu hamil yang mengalami anemia}

Berdasarkan penelitian yang telah dilakukan di UPT Puskesmas Kampar didapatkan hasil uji statistic dengan menggunakan uji $\mathrm{T}$ sampel didapatkan hasil bahwa besarnya nilai $p$-value 0.000 dengan $\alpha 0,05$. Karena nilai $p$-value $<0,05$, dengan demikian dapat 
disimpulkan bahwa Ha diterima yang artinya ada pengaruh konsumsi jus bayam merah jeruk sunkis-madu terhadap peningkatan kadar hemoglobin pada ibu hamil yang mengalami anemia di UPT Puskesmas Kampar Tahun 2019.

Hasil penelitian ini sejalan dengan penelitian yang dilakukan oleh Merida (2014) yang berjudul "Efektifitas terapi kombinasi jus bayam dan tomat terhadap peningkatan kadar hemoglobin pada ibu hamil dengan anemia". Hasil penelitian ini menyatakan bahwa pemberian terapi kombinasi jus bayam dan tomat dapat meningkatkan kadar hemoglobin ibu hamil dengan anemia dengan $p(0.013)<\alpha$ $(0,05)$.

Hasil penelitian ini juga sejalan dengan penelitian yang dilakukan oleh Wijayanti (2006) yang berjudul "Uji efektifitas jus bayam dalam meningkatkan kadar hemoglobin darah tikus putih (RattusNovergicus)". Berdasarkan hasil analisis dengan uji Anova satu faktor yang dilanjutkan dengan uji Duncan's menunjukkan bahwa terdapat efektifitas pemberian jus bayam dalam meningkatkan kadar hemoglobin darah tikus putih.

Bayam merah adalah dari tumbuhan keluarga Amaranthacea, sering juga disebut bayam glatik. Nama saintifiknya adalah Amaranthacea Gangeticus. Tumbuhan ini berasal dari Amerika tropic namun sekarang tersebar keseluruh dunia. Bayam merupakan tumbuhan yang biasa ditanam untuk dikonsumsi daunnya sebagai sayuran. Tumbuhan ini dikenal sebagai sayuran sumber zat besi yang penting terutama untuk dikonsumsi oleh ibu hamil (Wikipedia, 2017). Bayam salah satu sayuran yang banyak mengandung zat besi, dimana zat besi merupakan salah satu nutrien yang sangat penting dikonsumsi selama hamil (Bobak, 2008). Untuk $100 \quad$ gr bayammerahmengandungenergise besar $50 \mathrm{Kkal}, 3$ gr protein, 0,8 gr lemak, 10 gr karbohidrat, $520 \mathrm{mg}$ kalsium, 2,2 gr serat, $7 \mathrm{mg}$ zat besi dan $62 \mathrm{mg}$ vitamin C. Untuk itu pencegahan agar tidak terjadinya anemia sebaiknya mengkonsumsi bayam terutama bayam merah yang memiliki kandungan zat besi dan vitamin $\mathrm{C}$ yang lebih tinggi dibandingkan dengan bayam hijau. Adapun kebutuhan zat besi untuk ibu hamil > $20 \mathrm{mg}$. Besi adalah salah satu nutrien yang tidak dapat diperoleh dalam jumlah yang adekuat dari makanan yang dikonsumsi selama hamil (Bobak, Lowdermilk, Jansen 2004). Karena merupakan zat yang sulit diserap oleh tubuh maka dibutuhkan vitamin $\mathrm{C}$ agar zat besi dapat diserap secara maksimal. Hal ini sesuai dengan hasil penelitian Zulaekah (2007) yang menyatakan bahwa pemberian suplemen zat besi dan vitamin $\mathrm{C}$ lebih efektif meningkatkan kadar hemoglobin dan jumlah sel darah merah dibandingkan pemberian zat besi saja atau vitamin $\mathrm{C}$ saja.

Salah satubuah yang memiliki vitamin $\mathrm{C}$ dan senyawa bermanfaat untuk kesehatan adalah jeruk. Selain banya 
kmengandung vitamin $\mathrm{C}$ jeruk juga merupakan buah yang enak untuk dikonsumsi. Setiap 100 gram buah jeruk yang dikonsumsi mengandung $70 \mathrm{mg}$ vitamin $\mathrm{C}$ (Lean, 2013). Peneliti memilih untuk menggunakan jenis jeruk sunkis karena selain kaya vitamin $\mathrm{C}$ jeruk sunkis juga mengandung zat lainnya yang diperlukan saat kehamilan. Buah jeruk ini mengandung vitamin $\mathrm{C}$, vitamin B1, provitamin A, asamfolat, pektin, tanin, fosfor, kalsium, karbohidrat, besi, asamsitrat, flavonaid, glikosida, alkaloid, dan ester (Rozaline, 2006).

Madu merupakan obat dari segala jenis penyakit. Kandungannya yang baik bagi tubuh sehingga madu dapat dikonsumsi sebagai suplemen dalam kehidupan sehari-hari. Madu mengandung banyak mineral seperti natrium, kalsium, magnesium, aluminium, besi, fosfor, dan kalium. Vitaminvitamin yang terdapat dalam madu adalah thiamin, riboflavin (B2), asam askorbat, piridoxin, niasin, asampantotenat, biotin, asamfolatdan vitamin K. Salah satu cara pemanfaatan madu adalah dengan menambahkan atau mencampurkan herbal yang memiliki khasiat untuk memelihara kesehatan, mengobati penyakit dan perawatan tubuh. Kombinasi herbal dan madu akan meningkatkan kekuatan dalam mengobati penyakit (Suranto, 2004). Oleh sebab itu, tidak diragukan lagi selain digunakan sebagai perisa (pemanis) bagi jus, madu juga dapat dimanfaatkan khasiatnya bagi kehamilan.
Asumsi peneliti bahwa
terapi komplementer dengan mengkonsumsi kombinasi jus bayam merah-jeruk sunkis-madu dapat menjadi alternative bagi ibu hamil dalam meningkatkan kadar hemoglobin terutama bagi ibu hamil yang mengalami anemia ataupun bagi ibu hamil yang tidak mengkonsumsi tablet Fe. Selain itu juga dapat meningkatkan stamina, kesehatan janin dan memperkuat hingga menjaga kekuatan kandungan.

\section{DAFTAR PUSTAKA}

Amiruddin. 2009. Studi Kasus Kontrol Faktor Biomedis Terhadap Kejadian Anemia Ibu Hamil Di Puskesmas Bantimurung. Jurnal Medika UNHAS.

Ai Yeyeh Rukiyah. 2009. Asuhan kebidanan kehamilan. Jakarta : Trans Info Media.

Bobak. Lowdermilk. \& Jensen. 2008. Buku ajar keperawatan maternitas. Jakarta : EGC.

Burn, Grove. 2008. Konsep dan penerapan metodologi penelitian ilmu keperawatan. Jakarta.

Cookpad. 2017. Resep jus Bayam. Jakarta.

Dahlan, M. Sopiyudin. 2009. Besar sampel dan cara pengambilan sampel dalam penelitian kedokteran dan kesehatan. Jakarta : Salemba Medika.

Deherba. 2017. Obat herbal. Bogor : PT Deherba Indonesia.

Dokter sehat. 2017. Informasi kesehatan. Jakarta.

Fatmah. 2010. Gizi dan Kesehatan Masyarakat Edisi Revisi. Jakarta : PT. Raja Grafindo Persada. 
Hallo netizen Bilhio. 2017. cara pengolahan jus bayam. Jakarta.

Hastono, Sutanto. 2007. Analisa data kesehatan. Jakarta : Universitas Indonesia.

Hidayat, A.A. 2014. Metode penelitian keperawatan dan teknis analisis data.Jakarta : Salemba Medika.

Kemenkes RI. 2010. Masalah anemia gizi dan pencegahannya. Jakarta.

Manuaba. 2010. Ilmu kebidanan penyakit kandungan dan $K B$. Jakarta : EGC.

Merida, N. 2014. Efektifitas terapi kombinasi jus bayam tomat terhadap peningkatan kadar hemoglobin pada ibu hamil dengan anemia. JOMPSIK UNRI. $1-9$.

Notoatmodjo, S. 2010. Metodologi penelitian kesehatan.Jakarta : Rineka. Cipta.

Nursalam. 2008. Konsep dan penerapan metodologi penelitian keperawatan. Jakarta.

Pieter, Herry Zan. 2010. Pengantar psikologi dalam keperawatan. Cetakan I. Jakarta : Kencana Prenada Media Group.

Prawirohardjo, Sarwono. 2009.Ilmu kebidanan. Jakarta : Yayasan Bina Pustaka Sarwono Prawirohardjo.

Prawirohardjo, Sarwono, dkk. 2012. Ilmu Kebidanan Edisi III. Jakarta : Yayasan Bina Pustaka sarwono Prawirohardjo.

Rukiyah, A, Y, dkk. 2009.Asuhan Kebidanan I ( Kehamilan ). Jakarta : Trans Info Media.

Rozaline. 2008. Terapi jus buah \& sayur. E-book : Puspa Swara.

Sehat center. 2017. Cara Mencegah Anemia pada Ibu Hamil. Jakarta.
Setiadi. 2007. Konsep dan penulisan riset keperawatan. Yogyakarta : Graha Ilmu.

Subagio. 2008. Prinsip Dasar Ilmu Gizi. Jakarta : Gramedia Pustaka Utama.

Suranto, A. 2008. Khasiat dan manfaat madu herbal. Jakarta : Agromedia Pustaka.

Suririnah. 2008. Buku Pintar Kehamilan \& Persalinan: Panduan bagi calon ibu untuk menjalani kehamilan yang sehat \& menyenangkan. Jakarta: PT. Gramedia Pustaka Utama.

Tips Masa Kehamilan. 2017. 7 Manfaat Jus Jeruk untuk Ibu Hamil. Jakarta : Prenagen com.

Varney, Helen. 2009. Buku Ajar Asuhan Kebidanan Edisi 4. Jakarta : EGC.

Vitahealth. 2008. Seluk-beluk pengobatan alternatif dan komplementer. Jakarta : PT Buana Ilmu Populer (kelompok Gramedia).

Wikipedia bahasa Indonesia. 2017. Bayam. Diunggah pada tanggal 18 Agustus 2017 https://id.wikipedia.org/wiki/Baya $\underline{\mathrm{m}}$.

Wikipedia bahasa Indonesia. 2017. Jeruk. https://id.wikipedia.org/wiki/Jeruk

Wikipedia bahasa Indonesia. 2017. Madu.

https://id.wikipedia.org/wiki/Mad u.

Zulaiekah, S. 2007. Efek suplemen besi, vitamin $c$ dan pendidikan gizi terhadap perubahan kadar hemoglobin anak sekolah dasar yang anemia di kecamatan Kartasura Kabupaten Sukoharjo.Program pascasarjana : Magister GiziMasyarakat 
83 I $P$ E N ARUH PEMBERIAN JUS BAYAM MERAH, JERUK

SUNKIS, MADU TERHADAP KADAR HEMOGLOBIN PADA IBU

HAMIL YANG MENGALAMIANEMIA DI UPT PUSKESMAS

KAMPAR TAHUN 2019

Universitas

Diponegoro

Semarang. (Tesis).

Zulhaida, Lubis. 2008. Status Gizi Ibu

Hamil Serta Pengaruhnya

Terhadap Bayi yang Dilahirkan.
Available

at http://www.google.com. Accessed on April 2011. 